\title{
Application of waqf for social and development finance
}

\author{
Salman Ahmed Shaikh
}

Universiti Kebangsaan Malaysia, Selangor, Malaysia

Abdul Ghafar Ismail

Universiti Islam Sultan Sharif Ali, Bandar Seri Begawan, Brunei, and

\author{
Muhammad Hakimi Mohd Shafiai \\ Faculty of Economics and Management, Universiti Kebangsaan Malaysia, \\ Selangor, Malaysia
}

5

Received 23 August 2016 Revised 5 December 2016 7 February 2017 Accepted 10 February 2017

\begin{abstract}
Purpose - This paper aims to discuss the application of waqf (endowment) in the social finance sector for funding social and development projects and services.

Design/methodology/approach - The study is qualitative. It reviews literature and provides descriptive data to present its main idea.

Findings - Most Muslim-majority countries are generally income-poor, and the governments are generally weak in their tax collection, effective governance and capacity for development spending. Private sector financial institutions are scarce and mostly cater to the people who can meet the income-based lending criteria. Thus, the institution of waqf can fill the gap as a social finance institution by providing intermediation services for effectively utilising perpetual social savings. Flexibility in the rules of waqf enables it to serve beneficiaries directly or through financial institutions and to provide a wide range of social services.
\end{abstract}

Research limitations/implications - This conceptual research highlights the need and potential of waqf without discussing the regulatory and operational details of how to effectively institutionalize it in different regions.

Practical implications - The institution of waqf can harness the potential of selfless charitable giving in an effective way for better economic impact in the targeted social segments of society.

Originality value - The paper suggests the establishment of waqf-based training and vocational centres which will increase opportunities of self-employment and contribute in upward social mobility of beneficiaries.

Keywords Waqf, Charitable giving, Selfless behaviour

Paper type Research paper

\section{Introduction}

According to The World Bank (2016), 767 million people are estimated to be living below the international poverty line of US\$1.90 per person per day. On the other hand, there has been an unprecedented change in income disparity between the poor and the rich during the past

(C) Salman Ahmed Shaikh, Abdul Ghafar Ismail and Muhammad Hakimi Mohd Shafiai. Published in the ISRA International Journal of Islamic Finance. Published by Emerald Publishing Limited. This article is published under the Creative Commons Attribution (CC BY 4.0) licence. Anyone may reproduce, distribute, translate and create derivative works of this article (for both commercial and non-commercial purposes), subject to full attribution to the original publication and authors. The full terms of this licence may be seen at http://creativecommons.org/licences/by/4.0/legalcode

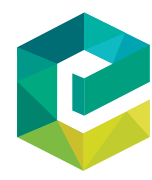

ISRA International Journal of Islamic Finance Vol. 9 No. 1,2017

pp. 5-14
Emerald Publishing Limited 0128-1976 DOI 10.1108/IJIF-07-2017-002 
IJIF

9,1

half century. According to Oxfam (2017), the richest eight people own as much wealth as half of the world's population. The question is: Do we really have scarcity of resources because of which we cannot end poverty, hunger and famine? Nobel laureate Sen (1981) did research on famine in Bengal and argued that the famine was not caused by lack of resources. Interestingly, according to the Food and Agriculture Organization (2013), for the world as a whole, per capita food supply rose from about 2,200 kcal a day in the early 1960 s to more than $2,800 \mathrm{kcal}$ a day by 2009 .

The world has enough resources to feed everyone, but the resources are not equitably distributed. The level of inequality has increased tremendously in the past 50 years. Piketty (2014) writes that 60 per cent of the increase in US's gross domestic product (GDP) since 1977 has accrued to the richest 1 per cent of the population. Similarly, countries in the Organisation for Economic Cooperation and Development in general also experience higher levels of income inequality today. People in the top 10 per cent of the income distribution get almost 10 times as much average income as people in the bottom 10 per cent of the income distribution (OECD, 2011).

While the developed world needs to find answers for egalitarian distribution of income, the developing world has to achieve both a decline in poverty as well as egalitarian distribution of income. Most of the Muslim-majority countries are generally poorer than other countries on average. Most of world poverty resides in Africa and Asia, and the bulk of Muslim-majority countries are located in these continents. Alpay and Haneef (2015) note that in the 57 Organisation of Islamic Cooperation (OIC) member countries, 31 per cent of the total population lives in poverty with average incomes below US\$1.25 per day. In Pakistan, Naveed and Ali (2012) conclude that around 59 million people are living in multidimensional poverty. Other Muslim-majority countries like Bangladesh and Nigeria have poverty headcount ratios of 43 and 62 per cent, respectively (The World Bank, 2015a).

Thus, in a largely income-poor Muslim world, there is enormous need for development spending and infrastructure. However, the size and scope of formal-sector financial institutions is small and concentrated. On the other hand, governments are also weak in effective governance and have limited revenue collection to instigate any meaningful longterm development plans. In this scenario, the role of the third sector becomes highly important. The institution of waqf in the Islamic social finance framework provides a useful vehicle to fill the gap in social intermediation. This study explores the potential and application of the institution of waqf in social and development finance through effective social intermediation between philanthropists and the needy.

The remainder of the paper is divided into five subsections. The second section presents some descriptive statistics on the economic underdevelopment in Muslim-majority countries which highlights the need for scaling up social and development finance. The third section then gives a relative comparison of motives in charitable spending in the mainstream and Islamic economic theoretical framework. The fourth section discusses the importance of waqf in the Islamic redistributive framework. The fifth section presents the contemporary applications of waqf in instigating development finance and projects which are geared to enhance skills, capacity and employability of the intended beneficiaries. The sixth section finally concludes the discussion and proposes steps to increase the effectiveness of waqf.

\section{Waqf as a social and development finance institution}

Because of high levels of poverty and weak governments, most of the Muslim-majority countries are behind in spending on schooling and health services. Hence, the level of human capital, productivity and national income remain at lower levels. Muslim-majority countries on average have lower literacy rates and primary school enrolment rates when we compare 
them against the high-income and middle-income countries as shown in Table I. Similarly, in health infrastructure, life expectancy and basic facilities like sanitation and water, it is observed that Muslim countries are far behind the high-income and middle-income countries.

Despite the fact that Muslim countries have higher average per capita income than the middle-income countries, the socio-economic performance of Muslim countries is still lower. This presents a case for effective financial and social intermediation to enable the surplus households who want to engage in continued philanthropic spending to help resourcedeficient households who require income and social assistance. However, financial intermediation in Muslim-majority countries focuses on commercially viable target markets and offers financing products which have income-based lending criteria for eligibility. The majority of income-poor households do not have sufficient or stable sources of income, and they lack asset ownership to qualify as bankable clients.

Could government instead scale up development spending and provide a wide range of welfare services as is the practice in the West? The fact is that welfare states in Europe usually have high tax collection. On the other hand, the governments in Muslim-majority countries have weak tax collection, and the public institutions are generally poorly governed. The World Bank (2015b) reveal that OIC countries have very poor governance performance. None of the OIC countries features in the top 50 countries with strong governance in 2015 on a composite index which includes voice and accountability, political stability, government effectiveness, regulatory quality, rule of law and control of corruption.

In this scenario, third sector social finance institutions could fill the gap in providing effective social intermediation within the country. In addition to that, across countries, we know that there is huge disparity in economic conditions between oil-rich and industrializing countries in the Gulf Cooperation Council and East Asia, respectively, and the rest of the OIC member countries in Africa and South Asia. With transnational waqf and country-to-country support programmes among the Muslim-majority countries, waqf-based social intermediation can help to improve the underdevelopment problems of the Muslim ummah (community).

\begin{tabular}{|c|c|c|c|c|}
\hline Indicators & $\begin{array}{l}\text { High-income } \\
\text { countries }\end{array}$ & $\begin{array}{l}\text { Middle-income } \\
\text { countries }\end{array}$ & $\begin{array}{l}\text { Muslim } \\
\text { countries }\end{array}$ & \\
\hline \multicolumn{5}{|l|}{ Economic } \\
\hline GDP per person employed (Constant 2011 PPP, USD) & 76,507 & 29,631 & 40,341 & \\
\hline Poverty ratio at PPP US $\$ 1.90$ a day ( $\%$ of population) & 0.56 & 5.95 & 24.58 & \\
\hline Gross fixed capital formation ( $\%$ of GDP) & 21.95 & 24.50 & 22.87 & \\
\hline \multicolumn{5}{|l|}{ Education } \\
\hline Literacy rate ( $\%$ of adult population) & 98.46 & 93.22 & 73.46 & \\
\hline Net enrolment ratio in primary $(\%)$ & 96.92 & 92.34 & 85.55 & \\
\hline Government expenditure on education ( $\%$ of GDP) & 5.19 & 4.67 & 3.69 & \\
\hline \multicolumn{5}{|l|}{ Health } \\
\hline Health expenditure ( $\%$ of GDP) & 8.75 & 6.20 & 5.18 & \\
\hline Hospital beds (per 1,000 people) & 5.18 & 3.37 & 1.98 & Table I. \\
\hline Improved sanitation facilities ( $\%$ people with access) & 97.14 & 81.85 & 64.53 & \\
\hline Improved water source (\% people with access) & 99.28 & 91.89 & 82.04 & Comparison of socio- \\
\hline Life expectancy (years) & 79.06 & 71.69 & 66.53 & $\begin{array}{r}\text { economic indicators } \\
\text { across country }\end{array}$ \\
\hline Source: The World Bank (2015a) & & & & groups \\
\hline
\end{tabular}

Application of waqf

7

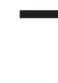



Islamic economics explain the motivation to spend in charitable causes. Charitable giving poses a unique challenge to the self-interested microeconomic agent that is known by the name of homo-economicus in neo-classical economics. Charitable spending exceeds 2 per cent of GDP in the USA alone (List, 2011). Alam (2010) contends that the annual philanthropic giving in Muslim communities could be as high as US\$1tn. A national level study by the Aga Khan Foundation in Pakistan reveals that private charitable giving is four times as much as the amount of the foreign aid received by the country (Alam, 2010).

The question that arises is: How can philanthropic behaviour be explained? In neoclassical literature on utility maximisation stream, social interactions were first explored by Becker $(1974,1976)$. Later on, Andreoni $(1989,1990)$ argued that people engage in impure altruism when they contribute in charity or donate for public goods. These charitable acts also emanate from self-interest, i.e. to gain fame, satisfy the ego or change the living environment to improve one's own social experience and relations. Other motives identified in the literature include moral satisfaction generated by contributing (Crumpler and Grossman, 2008), peer pressure which triggers reluctant altruism (DellaVigna et al., 2009), redeeming one's public image and avoiding the guilt of saying no (Andreoni and Bernheim, 2009) and public prestige (Harbaugh, 1998).

From this discussion, it appears that the empirical literature in neo-classical economics confines socially empathetic behaviour within a materialist and self-interested paradigm. Nonetheless, strengthening a person's moral commitment towards social needs should not be ignored as altruistic behaviour is also learnt like other behaviours (Mayr et al., 2009). Hence, to promote charitable spending, the right form of learning, as well as reinforcement and permanent incentives, are required.

Now, we attempt to explain the reinforcing incentives in the Islamic two-world framework for charitable spending. In the theoretical literature on Islamic economics, Sadeq (1987) explains that the Islamic concept of human welfare is more comprehensive than economic welfare alone. In line with this, Chapra (1999) contends that economic development is one part of human wellbeing. Economic development on its own is insufficient to actualize all-encompassing human wellbeing. After the rise in income inequality which followed economic growth in the post-Second World War era and the subsequent ecological and environmental challenges which appeared as a result of the capitalist growth model, the Western concept of development has also given way to wider dimensions of human development and recognition of the role of institutions (Mirakhor and Askari, 2010).

In the Islamic worldview, human welfare is only complete when it is achieved in both worlds, i.e. the temporal worldly life and the everlasting afterlife. The Islamic worldview provides a larger perspective and incentive structure for righteous actions in the two-world framework of life. This has the potential to result in comparatively higher willingness for social actions, affirmative participation in social causes, higher charitable giving and exhibition of more selfless behaviour in social relations and in the marketplace.

The Qur'ān says, "By no means shall you attain righteousness unless you give [freely] of that which you love" (3: 92). The Prophet (peace be upon him) once said:

When a man dies, all his acts come to an end, except three: recurring charity (sadaqah jarriyah), or knowledge by which [people] benefit, or a pious offspring who prays for him (Sahih Muslim, Book of Wills, Hadīth No. 4005).

Hence, in the Islamic framework, the incentives for socially empathetic behaviour come from a distinct worldview and comprehensive notion of social responsibility and ethical 
behaviour. These are ingrained in faith-consciousness which ultimately affects preferences and economic and non-economic choices.

\section{The importance of waqf in the Islamic redistribution framework}

Waqf is an important institution in the Islamic social framework. It can harness the potential of selfless charitable giving in an effective way for better economic impact in the targeted social segments of society.

Under waqf, an owner donates and dedicates an asset (movable or immovable) for permanent societal benefit. The beneficiaries enjoy its usufruct and/or income perpetually. In the contemporary application of waqf, it can be established either by dedicating real estate, furniture or fixtures, other movable assets and liquid forms of money and wealth like cash and shares.

The cash waqf is usually formed where the pooled donations are used to build institutions, such as schools, hospitals and orphanages (Sadeq, 2002). Aziz et al. (2013), argue that cash waqf can pool more resources and ensure wider participation of individual donors.

One of the important features of waqf is that it provides flexibility in fund utilisation as compared to $z a k \bar{a} h$ (almsgiving). Zakāh funds must be utilised for specific categories of recipients. On the other hand, the institution of waqf can be used to provide a wide range of welfare services to Muslims as well as non-Muslims, and the beneficiaries could also be other living beings. For instance, animal protection programmes and environmental preservation expenditures can be provided more flexibly through waqf. The institution of waqf can transform social capital into social and public infrastructure. It provides a permanent social safety net in the case of perpetual waqf to the beneficiaries.

The institution of waqf complements the institution of $z a k a \bar{h}$ because the government cannot take more than a prescribed portion of wealth as zakāh. Hence, the private establishment of waqf helps in sharing the burden of the exchequer and also provides a source of contentment for the faithful donor in following the Islamic directives on charitable spending. The institution of waqf is also an excellent source of building religious infrastructure for Muslims in Europe, America and Australia where non-Muslims are the majority and governments are mostly secular and not interested in providing funds for religious infrastructure like mosques. In such countries, Muslims can share infrastructure like schools and hospitals built by the government for all citizens. However, they cannot share the religious infrastructure with non-Muslims, and the government is unlikely to pay attention to the religious needs of minority Muslims in such secular-oriented countries.

As compared to individual charity, the institution of waqf is more effective in matching right targets with objective screening and providing sustainable sources of funds to the beneficiaries. In individual charity, rich people often face difficulty in finding the right targets because their extended families and social circle normally comprise people like themselves.

Besides income support and cash transfers, poor people need training, capacity building and skills improvement to get out of poverty and achieve social mobility. Haneef et al. (2014) argue that lack of finance and business training requires institutional support to unleash the potentials of micro-entrepreneurs and to establish viable micro-enterprises. Obaidullah (2008) explains that growth-oriented micro-finance programmes also need to provide training, insurance, and skills enhancement facilities. In this regard, the institution of waqf can improve the chances of socio-economic mobility by providing a rather permanent, effective and efficient funding source for the health and education infrastructure. The increased and improved provision of education and health infrastructure funded through waqf can enhance the income-earning potential of beneficiaries. 
In Muslim history, awqāf (pl. of waqf) provided public utilities (roads, water and sewage), educational institutions and hospitals. Even staunch critics of Islamic economics, such as Kuran (2001) concede that the institution of waqf delivered public goods in a decentralised manner in Muslim economies for a long period of time. Even in contemporary times, awqa $\bar{f}$ can also directly affect entitlements by providing educational scholarships and health services for the poor. Hence, the institution of waqf can help in capacity building and wealth creation through building human, physical and financial capital.

\section{Application of waqf in a contemporary policy framework}

In the contemporary application of waqf, it can be established either by dedicating movable or immovable asset(s). This provision enables people to contribute in establishing a waqf even if they do not personally own any real estate. Mohammad et al. (2006) suggest that if we keep a distinction between the perpetuity of the object itself and its "dedication" of benefits, then we can effectively use the institution of waqf in contemporary economies. They argue that only the value capital is to be preserved perpetually, whereas the investment capital may be transformed into different types of assets as deemed fit for maximizing the benefits from the waqf.

With regards to the management, administration and governance aspect of waqf in contemporary times, many scholars also highlight the importance of professional management and transparent administration of waqf for effective results. Alpay and Haneef (2015) recommend that there must be transparency and accountability between funding and implementing agencies for achieving the ultimate goal of poverty reduction. In the same line of thought, Hassan and Shahid (2010) argue that professional business management will improve institutional quality, service delivery and effective delegation of responsibility so as to ensure and ease accountability. Hence, corporate structure is suitable for professional management and perpetuity. Sulaiman et al. (2009) argue that transparency is vital in operations as well as in reporting so that the trust deficit is reduced between the donors and the waqf administration.

Another important aspect in the application of waqf in contemporary times is the sustainability of waqf institutions. Dafterdar (2011) argues that sustainability is complimented by profitability. Thus, seeking profits could create surplus which can help in expanding or at least sustaining the net of social services adequately. Otherwise, if we rely solely on cash donations and do not hedge against declining purchasing power of money in a cash waqf, the risk of non-sustainability could increase. Obaidullah (2016) emphasizes that preservation of benefits for the intended beneficiaries requires prudent management of the assets and efficiency in their development and investment. Sulaiman and Zakari (2013) emphasize the importance of diversity in income sources for waqf institutions. In making investments, it is better to engage quality investment management specialists to protect and achieve growth in the pooled funds over time.

The permissibility of making waqf with contemporary forms of wealth like cash and shares increases flexibility and widens participation. Mohammad (2011) explains that waqf can be used to establish new financial, commercial and social sector institutions. Waqf with large funds can also become a superstructure under which other commercial and welfare institutions can be established. In this regard, Habib (2007) proposes a waqf-based Islamic microfinance institution. Habib (2007) suggests that Islamic banks can use income derived from late-payment penalties and other proceeds to establish these institutions. Mohammad (2011) argues that because commercial banks usually miss the poorer clients, cash waqfbased Islamic banks can provide more compassionate and egalitarian services. Because the people establishing cash waqf will not have as much target profit in mind as the investors in 
commercial banks, the waqf management can use the funds in a more flexible way in financing social needs as well as providing benevolent loans to the ultra-poor. Mohammad (2011) suggests that the cash waqf model can be used to provide capital for the waqf bank.

In developing countries, the masses of poor people do not have access to financial services either because of supply-side sluggishness or unavailability of supporting services. Saad and Anuar (2009) argue that, for commercial reasons, microfinance programmes usually miss the ultra-poor and hence commercial microfinance is ineffective in reducing poverty. The evidence from countries with high penetration of microfinance reveals that poverty has not been reduced by much there. The ultra-poor severely lack access to complementary services, which reduces the marginal benefit of access to finance relative to the moderately poor. That is where the institution of waqf could support microfinance beneficiaries in enhancing the non-income aspects of their human capital potential.

Rahman and Dean (2013) highlight that it is important to utilise the institutions of waqf and $z a k \bar{a} h$ for capacity building of the poor so that they can build skills for income generation and subsequently become marketable clients for microfinance. The waqf model can be used to fund the establishment of training and business support centres. The recurring costs can be managed by taking a fee-in-kind in terms of requiring the trained person to further train some fixed number of clients. Hence, no monetary fee would be charged for training facilities, but the person provided with training shall further train other people so that the model becomes financially sustainable. In turn, maximum leverage can be obtained from the funds that are used to establish these centres and for training the first few groups of people.

These training centres would complement the financing functions of microfinance institutions as the people with required human capital are expected to be more productive and, hence, earn income levels that can cover the cost of financing and leave some surplus for the client.

It is an empirical reality that people want to donate both time and money. Hence, professionals like doctors and academicians can donate voluntary time to be part of such training centres. Such non-monetary donation will enable them to contribute to social causes without having to become a permanent part of the institutions and leave their primary bread-earning occupation. It will also enable them to be part of social projects without having to worry about administration, necessary infrastructure and finding suitable targets. This would also reduce their cost of donation by reducing transaction costs, and it would help them to donate more time in actual service delivery than in incurring transaction costs of matching the right targets.

Lastly, the institution of waqf can also be used to finance public infrastructure and public goods like roads, schools and hospitals. Such complimentary public investments are one of the prime sources of continuous economic growth (Romer, 1986).

\section{Conclusion and recommendations}

This paper argues that the motives and incentive structures for charitable giving in Muslim societies are different from secular societies. This difference arises because of the distinct Islamic worldview and inspiration from Islamic sources of knowledge for social and moral attitudes to life. It is argued that the institution of waqf is an important institution in the Islamic social framework and that it can harness the potential of selfless charitable giving in an effective way for better economic impact in the targeted social segments of society.

In light of various economic indicators, the paper presented how waqf can contribute in social finance as a complementary alternative to governments and private-sector financial institutions which cannot undertake all socially desirable projects because of lack of funds or commercial non-viability. 
$\mathrm{IJIF}$

9,1

Some recommendations for increasing the effectiveness of the institution of waqf in contemporary applications are listed below:

- It is vital to improve the matching technology. Charitable spending can be seasonal and impulsive. Hence, there is a need for accessible avenues to match targets and mobilise resources efficiently.

- Sourcing philanthropic contributions online in cash waqf can be more efficient and bring more participation, especially in the case of emergencies (Yusof et al., 2014). It can also help in capitalizing on short-term impulsive empathetic spending on special occasions and events.

- In soliciting waqf contributions or investments in waqf certificates, it is necessary to highlight the positive externalities as suggested in the experimental economics literature (Andreoni, 1995). For instance, it is important to highlight how much difference a contribution of RM 1,000 will make in funding one year schooling of a certain number of children.

- It is important to provide tax incentives to engage more people and corporations in establishing awqāf. Shirazi (2014) urges the Islamic Development Bank (IDB) to encourage cash $a w q \bar{a} f$ with tax incentives to the endowers. Tax deductibility for corporations can be one such incentive that should be allowed by countries where tax incentives are yet to be allowed. Furthermore, tax rebates on income deducted at source of waqf investments shall be allowed to reduce the tax burden on waqf.

- It is important to create social awareness for creating the right kind of waqf at the right place. For instance, in many Muslim countries, only mosques are built as waqf, and often very close to each other, whereas the majority of Muslims often face shortages of basic medical and educational services.

- The laws related to waqf must be simplified and standardised, especially for

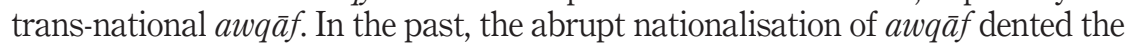
confidence of people. Thus, it is vital to ensure the independent status and operations of waqf.

\section{References}

Alam, N. (2010), "Islamic venture philanthropy: a tool for sustainable community development", Social Sciences Research Network Working Paper no. 1565859.

Alpay, S. and Haneef, M.A. (Eds) (2015), Integration of Waqf and Islamic Microfinance for Poverty Reduction: Case Studies of Malaysia, SESRIC \& IIUM, Kuala Lumpur.

Andreoni, J. (1995), “Cooperation in public-goods experiments: kindness or confusion?”, The American Economic Review, Vol. 85 No. 4, pp. 891-904.

Andreoni, J. (1989), "Giving with impure altruism: applications to charity and Ricardian equivalence", The Journal of Political Economy, Vol. 97 No. 6, pp. 1447-1458.

Andreoni, J. (1990), "Impure altruism and donations to public goods: a theory of warm-glow giving", Economic Journal, Vol. 100 No. 401, pp. 464-477.

Andreoni, J. and Bernheim, B.D. (2009), "Social image and the 50-50 norm: a theoretical and experimental analysis of audience effects", Econometrica, Vol. 77 No. 5, pp. 1607-1636.

Aziz, M., Johari, F. and Yusof, M.A. (2013), “Cash waqf models for financing in education”, Proceedings of the 5th Islamic Economic System Conference (iECONS2013), available at: www.researchgate. net (accessed 21 March 2017). 
Becker, G.S. (1974), “A theory of social interactions”, Journal of Political Economy, Vol. 82 No. 6, pp. 1063-1093.

Becker, G.S. (1976), The Economic Approach to Human Behavior, The University of Chicago Press, Chicago.

Chapra, M.U. (1999), "Islam and economic development: a discussion within the framework of Ibn Khaldun's philosophy of history", Second Harvard University Forum on Islamic Finance: Islamic Finance into the 21st Century: Proceedings of a Conference, Center for Middle Eastern Studies, Harvard University, Cambridge, MA, pp. 23-30.

Application of waqf

Crumpler, H. and Grossman, P.J. (2008), "An experimental test of warm glow giving”, Journal of Public Economics, Vol. 92 No. 5, pp. 1011-1021.

Dafterdar, M.H. (2011), “Toward effective legal regulations and an enabling environment for inalienable Muslim Endowments (awqaf)", Islam and Civilisational Renewal, Vol. 2 No. 4, pp. 654-668.

DellaVigna, S., List, J.A. and Malmendier, U. (2009), "Testing for altruism and social pressure in charitable giving", NBER Working Paper No. 15629, NBER, Cambridge, available at: www.nber. org/papers/w15629.pdf (accessed 21 March 2017).

Food and Agriculture Organization of the United Nations (2013), "Part 3: Feeding the World", FAO Statistical Yearbook 2013, FAO, Rome, pp. 173-181.

Habib, A. (2007), "Waqf-based microfinance: realizing the social role of Islamic finance", Paper Presented at the International Seminar on Integrating Awqaf in the Islamic Financial Sector, Singapore, 6-7 March.

Haneef, M.A., Muhammad, A.D., Pramanik, A.H. and Mohammed, M.O. (2014), "Integrated waqf based Islamic microfinance model (IWIMM) for poverty alleviation in OIC member countries", MiddleEast Journal of Scientific Research, Vol. 19 No. 2, pp. 286-298.

Harbaugh, W.T. (1998), "What do donations buy? A model of philanthropy based on prestige and warm glow", Journal of Public Economics, Vol. 67 No. 2, pp. 269-284.

Hassan, A. and Shahid, M.A. (2010), "Management and development of the awqaf assets", Paper Presented at the Seventh International Conference-The Tawhidi Epistemology: Zakat and Waqf Economy, Bangi.

Kuran, T. (2001), "The provision of public goods under Islamic law: origins, impact, and limitations of the waqf system", Law \& Society Review, Vol. 35 No. 4, pp. 841-898.

List, J.A. (2011), "The market for charitable giving”, The Journal of Economic Perspectives, Vol. 25 No. 2, pp. 157-180.

Mayr, U., Harbaugh, W.T. and Tankersley, D. (2009), "Neuroeconomics of charitable giving and philanthropy", in Glimcher, P.W. and Fehr E. (Eds), Neuroeconomics: Decision Making and the Brain, Academic Press, London, pp. 303-320.

Mirakhor, A. and Askari, H. (2010), Islam and the Path to Human and Economic Development, Palgrave Macmillan, New York, NY.

Mohammad, M. (2011), "Towards an Islamic social (waqf) bank", International Journal of Trade, Economics and Finance, Vol. 2 No. 5, pp. 381-386.

Mohammad, M., Iman, M. and Hamid, A. (2006), "Obstacles of the current concept of waqf to the development of waqf properties and the recommended alternative", Malaysian Journal of Real Estate, Vol. 1 No. 1, pp. 1-95.

Naveed, A. and Ali, N. (2012), Clustered Deprivation - District Profile of Poverty in Pakistan, Social Development Policy Institute (SDPI), Islamabad.

Obaidullah, M. (2008), "Role of microfinance in poverty alleviation: lessons from experiences in selected IDB member countries", Islamic Development Bank, available at: https://papers.ssrn.com/sol3/ papers.cfm?abstract_id=1506077 (accessed 21 March 2017).

Obaidullah, M. (2016), "A framework for analysis of Islamic endowment (waqf) laws", International Journal of Not-for-Profit Law, Vol. 18 No. 1, pp. 54-64. 
OECD (2011), Divided we Stand: Why Inequality Keeps Rising, OECD Publishing, Paris.

Oxfam (2017), Oxfam Briefing Paper: An Economy for the 99\%, Oxfam Gb, Oxford.

Piketty, T. (2014), Capital in the Twenty-First Century, Belknap Press, New York, NY.

Rahman, R.A. and Dean, F. (2013), "Challenges and solutions in Islamic microfinance”, Humanomics, Vol. 29 No. 4, pp. 293-306.

Romer, P.M. (1986), "Increasing returns and long-run growth", The Journal of Political Economy, Vol. 94 No. 5, pp. 1002-1037.

Saad, N.M. and Anuar, A. (2009), "Cash waqf and Islamic microfinance: untapped economic opportunities", Islam and Civilisational Renewal (ICR), Vol. 1 No. 2, pp. 337-354.

Sadeq, A. (1987), "Economic development in Islam", Journal of Islamic Economics, Vol. 1 No. 1, pp. 35-45.

Sadeq, A.M. (2002), "Waqf, perpetual charity and poverty alleviation”, International Journal of Social Economics, Vol. 29 Nos 1/2, pp. 135-151.

Sen, A. (1981), Poverty and Famines: Essay on Entitlement and Deprivation, Clarendon Press, Oxford.

Shirazi, N.S. (2014), "Integrating zakat and waqf into the poverty reduction strategy of the IDB member countries", Islamic Economic Studies, Vol. 22 No. 1, pp. 79-108.

Sulaiman, M. and Zakari, M.A. (2013), "Efficiency and effectiveness of waqf institutions in Malaysia: toward financial sustainability", Paper Presented at the 9th International Conference on Islamic Economics and Finance, Istanbul, Turkey, 9-10 September.

Sulaiman, M., Adnan, M.A., Nor, M.M. and Suad, P.N. (2009), "Trust me! a case study of the international Islamic university Malaysia's waqf fund”, Review of Islamic Economics, Vol. 13 No. 1, pp. 69-88.

The World Bank (2015a), World Development Indicators 2015, The World Bank, WA.

The World Bank (2015b), Worldwide Governance Indicators, The World Bank Group, WA.

The World Bank (2016), Poverty and Shared Prosperity 2016: Taking on Inequality, The World Bank Group, WA.

Yusof, M., Hasarudin, M.H. and Romli, N. (2014), "Cash waqf and infaq: a proposed e-philanthropy in Malaysia”, Jurnal Kemanusiaan, Vol. 22, pp. 1-10.

\section{About the authors}

Salman Ahmed Shaikh is a PhD Scholar in Economics at Universiti Kebangsaan Malaysia. He has published several journal articles and book chapters on Islamic economics and finance. He has also taught in Pakistan at the Institute of Business Administration and SZABIST. Salman Ahmed Shaikh is the corresponding author and can be contacted at: salman@siswa.ukm.edu.my

Abdul Ghafar Ismail, PhD, is a Professor of Islamic Financial Economics at Universiti Islam Sultan Sharif Ali, Brunei Darussalam. He has also served as the Head of the research division, Islamic Research and Training Institute (IRTI), Islamic Development Bank (IDB) and as a Professor of Finance at Universiti Kebangsaan Malaysia. He has contributed many articles in scholarly journals and has published books as well as individual chapters in several books.

Muhammad Hakimi Mohd Shafiai, PhD, is a Senior Lecturer at Universiti Kebangsaan Malaysia. $\mathrm{He}$ received his $\mathrm{PhD}$ (Islamic Economics) from the Graduate School of Asian and African Area Studies, Kyoto University, Japan. He has written a book (Islamic Finance for Agricultural Development, 2013) and has published several scholarly articles related to Islamic economics.

For instructions on how to order reprints of this article, please visit our website:

www.emeraldgrouppublishing.com/licensing/reprints.htm

Or contact us for further details: permissions@emeraldinsight.com 